IP Periodica Polytechnica Architecture

48(1), pp. 28-34, 2017

https://doi.org/10.3311/PPar.11135

Creative Commons Attribution (i)

RESEARCH ARTICLE

\section{Frigyes Schulek's Calvinist Reformed Church in Szeged: A Particular Case of Medieval Design in Historicism}

\author{
Krisztina Fehér ${ }^{1}$, Balázs Halmos ${ }^{1}$, János Krähling ${ }^{1 *}$
}

Received 30 May 2017; accepted 08 June 2017

\begin{abstract}
Analysing the original drawings of Frigyes Schulek's Calvinist Reformed Church in Szeged from 1882 kept in the Plan Collection and Archives of the BME Department for History of Architecture and of Monuments, its design process of geometric proportioning method can be entirely reconstructed. The result of this analysis shows that the Historicism of Schulek was not merely the replication of stylistic patterns of Gothic art but also the application of Medieval architectural principals and ideas. In the case of the Calvinist Reformed Church in Szeged, the essence of the design 'in style' was inspired by the contradictions of the function and the position of the building beside the main theoretic recommendation of Protestant church architecture of the time (Eisenacher Regulativ). The purity of the interior required by the function was compensated by the complexity of the geometry. The analysis presented in the paper sheds light not only on Schulek's approach to Medieval architecture but also the various levels of Historicism in the 19th century. Schulek fulfilled the functional requirements of the Calvinist church interior by the reemployment of a typical gothic design method, partially evoking the theoretic principals of Medieval architectural design in the 19th century.
\end{abstract}

\section{Keywords}

Frigyes Schulek, Calvinist Reformed Church in Szeged, geometry, gothic

\footnotetext{
${ }^{1}$ Department of History of Architecture and Monument Preservation, Faculty of Architecture, Budapest University of Technology and Economics, Müegyetem rkp. 3., H-1111 Budapest, Hungary

*Corresponding author, e-mail: krahling@eptort.bme.hu
}

\section{Introduction}

The method of the study is the detailed examination of the remaining original plans of Frigyes Schulek's Calvinist Reformed Church in Szeged. With this type of analysis, all the pencil traces and drawing compass marks of the architect can be identified to provide as precise a reconstruction of the design process as possible. The method of direct observation of original architectural drawings has appeared in the recent literature, for instance, in Robert Bork's work analysing remaining Medieval plans of Gothic buildings in the quest for Medieval geometrical design techniques, and considering the drawing as the main media showing the concept of the architect. (Bork, 2011)

In the case of the Szeged Church, the unusual disposition of the floor plan gives particular relevance to the study of the original drawings. Comparing our observations with Schulek's paper on his conception (Schulek, 1885), the question of his theoretic approach can be understood more clearly. The single nave and the two dodecagonal apses of the church, in NeoGothic style, enframe a triangular crossing in the middle. The nave consists of three bays covered by ribbed cross vaults, the apses are likewise covered by ribbed vaults, and the crossing is emphasised by a star-shaped vault leaning on pointed arches. The communion table is in the exact centre of the crossing while the pulpit is placed behind it, in front of the pillar, on the main axis. (Fig. 1) This composition, as Frigyes Schulek stressed, served to enhance the communion table, being a less attractive piece of furniture, by placing it in the middle. ${ }^{1}$ Additionally,

1'Az »Úr asztala «mint asztal, szerény kiterjedésü egyszerü bútor, jelentőségét csak is kiváló helyzet által nyerhet, és ennélfogva mértanilag elsörendü helyre, a kellö középre állítandó. Mig ellenben a szószék már kiemelkedö alakja által is magára vonván a figyelmet, inkább állhat mértanilag másodrendü helyen; megokolja ezt a beszéd, a hang terjedésének természete is, mely hangverö hátvédelmet kíván, minek következtében azt célszerüen falhoz, vagy terjedelmes pillérhez fogjuk támasztani.' [This »communion table«, being a table, is a modestly dimensioned, simple piece of furniture, that gains importance only by its position; that is why it is to be placed in a geometrically primary situation, in the very centre. While the pulpit, attracting attention by its elevated shape, can rather stand in a geometrically secondary position; accounted also by the nature of the diffusion of speaking and voice, that demands a resonating background, therefore it should be braced to a wall or an extensive pillar.] (authors' translation) (Schulek, 1885. 7.) 


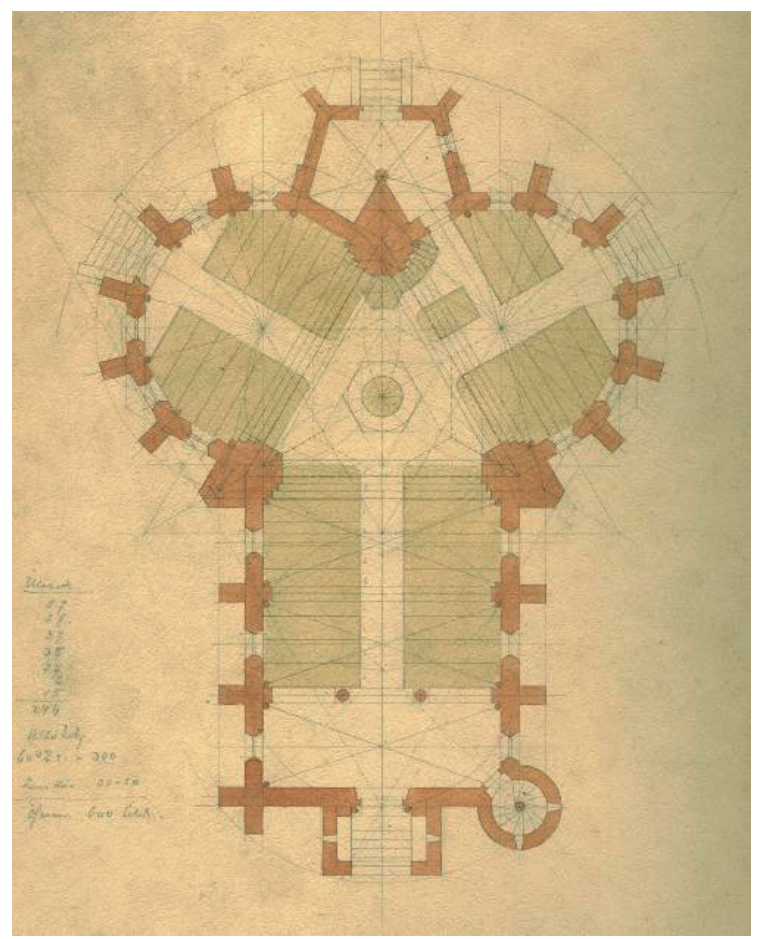

Fig. 1 Calvinist Reformed Church in Szeged, drawing of the floor plan, Frigyes Schulek, 1882 (Plan Collection and Archives of the Department of History of Architecture and of Monuments, no. 101795)

the more spectacular appearance of the pulpit is compensated by its less emphatic location so that the visual importance of these two main items could be balanced beside the acoustical advantages of the position of the pulpit. (Fig. 2)

\section{Circumstances of design - Idealisation of the Middle Ages}

In 1882, when Schulek started designing the new Calvinist Reformed Church in Szeged (Róka, 1999:p.27), the significance of the Eisenacher Regulativ set down in 1861 was indisputable. Respecting the principals of the Regulative, several Reformed churches were designed in typical Medieval style with a longitudinal disposition. ${ }^{2}$ This idealisation of the Middle Ages was undoubtedly related to the revival of Romanesque and Gothic styles both in architecture and fine arts. Being one of the most important personalities of this movement in Hungary in the second half of the $19^{\text {th }}$ century, Frigyes Schulek - similarly to his master Friedrich von Schmidt from Vienna - tried to study Medieval architecture as deeply as possible in order to adapt the knowledge in his works and educational practice. His generation of architects surveyed and examined hundreds of Medieval monuments as part of their university studies and later - on becoming professors - within the

2 For instance: Church of Schlieffenberg, 1854-59.; Church of Sonneberg, 1845.; Lutheran 'Marktkirche' Church of Wiesbaden, 1853-62.; CalvinistLutheran Church of Langenhagen in Hannover, 1859-64.; Saint-John Church of Dresden, 1874-78.; Church of Planitz, 1872-76.; Church of Ludwigshafen, 1859-73.; Church of Langen, 1880-83. (Kirchenbau, 1893. 232-283.)

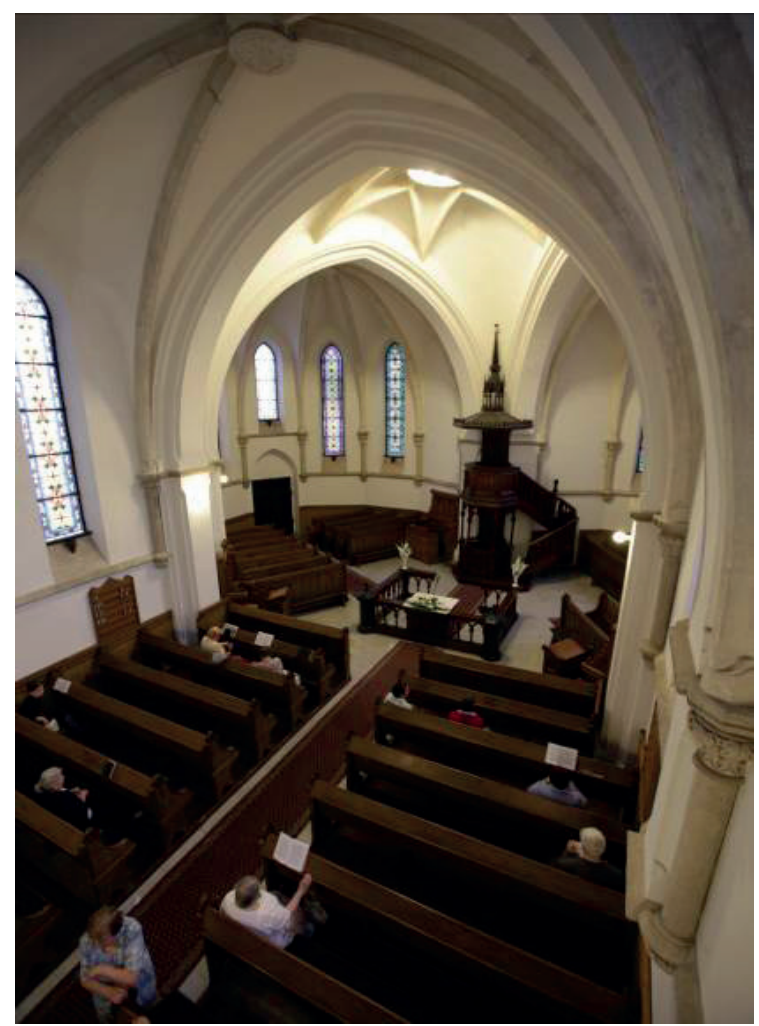

Fig. 2 Interior of Calvinist Reformed Church in Szeged (photo by Zorán Vukoszávlyev)

framework of university education following their research. Being the head of the Department of Medieval Architectural Studies of Royal Joseph University from 1903 to 1911, Schulek led the surveying of several historical monuments of Hungary. Some of these drawings can be examined in the Plan Collection and Archives of BME Department for History of Architecture and of Monuments. His heritage enlightens his enthusiastic approach towards Medieval architecture that can also be detected studying the original plans of the Calvinist Reformed Church in Szeged.

\section{Circumstances of design - Functional demands}

As the Eisenacher Regulativ defined the longitudinally shaped church interior as the one in accordance with Medieval principles, the strict scheme of the floor plan and the functional demands of reformed sacred spaces give rise to contradictions in general terms as well as in the particular case of the Szeged Church.

On the one hand, the communion table and the pulpit being in the middle of the space composition - in the nave, following Medieval tradition, lying closer to the chancel - assign a centre to the space, which does not fit well with the strictly longitudinal nave. On the other hand, according to the principles of $19^{\text {th }}$-century Reformed church architecture, no ornamental elements could be introduced. As Schulek expressed, the purity of walls and inner surfaces desired in Calvinist churches made the 
space empty and bare. ${ }^{3}$ In his opinion, the demand for purity lost the essence of Medieval church interiors that are colourful and rich in figures. ${ }^{4}$ He recognised the need for a huge and centralised space for the audience, the ideal of which he saw in the form of a 'circus' or theatre with balconies. He could not, however, design a church with this form and lose the possibility of installing high rising windows and create a clear and undivided space. ${ }^{5}$

\section{The design method}

Schulek found the solution for the contradiction between the functional requirements of a Reformed sacred space and the Medieval concept in the revival of a Gothic geometric design method called after its main figure triangulation. As he thought that the lack of ornamental decoration made the interior empty both in the aesthetic and figurative sense, he tried to find a compromise. As he expressed, the geometric design method was rich in ideas that replaced the richness of frescoes and statues in Medieval interiors. ${ }^{6}$

Schulek produced an entirely logical and coherent triangular geometric system for the design of the church floor plan, which can be reconstructed analysing the original plan from 1882 .

The basis of this method is the equilateral triangle of the crossing of the church in the intersection of the axes of the nave and the two apses. The radius of 4.7 meters of the circumcircle of this triangle was determined by the dimensions of the

3 'Ez a katolikusok temploma. A protestánsok átvették, (...) csak a festett és faragott képeket, jelvényeket, és a belsö felszerelésböl mindazt, mire szükségük nem volt, távolitották el. A fóalkotó rész, az épület meg megmaradt ... üresen!' [This is the church of the Catholics. The Protestants took it over, (...) only painted, carved images, emblems and what they did not need were removed. The main component, the building itself had remained ... as empty!] (authors' translation) (Schulek, 1885. 5.)

4 'Mert az eredeti katolikus typus szerint épült szentélyek és oltárfülkék üresek; mert a festett képek számára szánt falfelületek üresek (...). Vakitó világosság, monoton szinezet csak még jobban kiemeli ezt az általánosan ismert jellemzö vonásokat, a sivárság vonásait...' [Because the chancels and apses built after the original Catholic type are empty; because the wall surfaces devoted to painted images are empty (...). Blinding lightness, monotonous colours emphasise these generally known features even more, the features of desolation...] (authors' translation) (Schulek, 1885. 6.)

5 'A központositás elve legteljesebben jut érvényre a circusok tölcséralakú felületén és a színházaknak karzatos szervezetében. (...) A hosszúra felnyúló ablakokat az eléjük alkalmazott karzatok kétszer-háromszor megosztják. (...) Egyszóval a belsö hatás zavart, rossz és az ablakokon át a külsöre is kiható.' [The idea of centralisation comes to the full in the funnel shaped surface of circuses and the system of galleries of theatres. (...) The high ascending windows are divided into two or three parts by the galleries set in front of them. (...) In a word, the impression of the interior is disturbed, wrong and influences the exterior through the windows as well.] (authors' translation) (Schulek, 1885. 7.)

6 'Az összetett jó mértani rendszernek különben meg van az a nevezetes jó tulajdonsága, hogy számlálhatatlan sok mértani vonatkozásokat tartalmaz, vagyis eszmegazdagsága van.' [Anyway, the complex correct geometric system has the notable good characteristic of containing uncountable geometric aspects, thus it is rich in conceptions.] (Schulek, 1885. 8.) building plot (Schulek, 1885:p.11) Drawing this circumcircle, the thickness of the wall used all around the church can be constructed with the dimension between the circumcircle and its inner hexagon. (Fig. 3) With the duplication of the circle, the length of the nave can be drawn. Copying the circle on each side of the triangle, the circumcircles of the dodecagons of the apses can be created. (Fig. 4) Using the sides of the dodecagons parallel to the main axis and the length of the nave, the embordering equilateral triangle can be drawn, the median triangle of which provides the three main pillars of the church. (Fig. 5) The vaulting of the transept can be produced by the hexagon inscribed in the incircle of the first equilateral triangle. (Fig. 6) For the pentagon of the sacristy, the connection and alignment of the corners of the central hexagon and the corners of the dodecagons are needed. The eastern corners of the pentagon can be produced by arcs using the centre points of the dodecagons. (Fig. 7) The centre of the pentagon defines the thickness of the three main pillars of the church. The incircle of the pentagon provides the thickness of the walls of the sacristy. (Fig. 8) The dimensions of the outside piers supporting the vaulting of the nave and apses are determined by static calculations. ${ }^{7}$

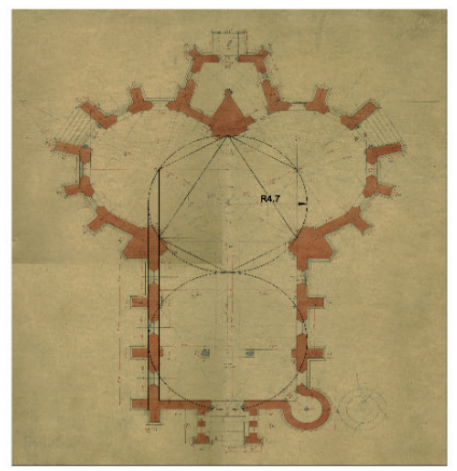

Fig. 3 Steps of the construction of the Calvinist church in Szeged (Plan Collection and Archives of the Department of History of Architecture and of Monuments, no. 101809)

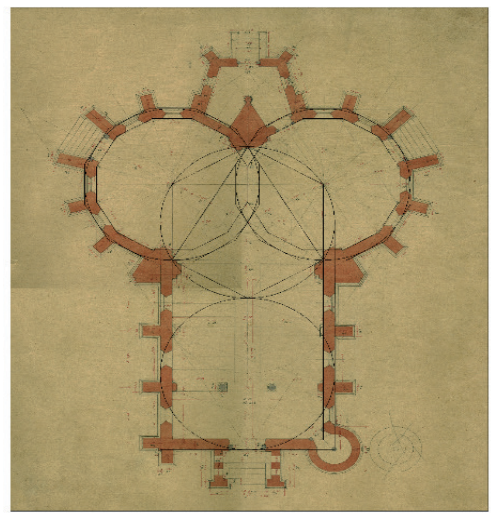

Fig. 4 Steps of the construction of the Calvinist church in Szeged (Plan Collection and Archives of the Department of History of Architecture and of Monuments, no. 101809)

7 Plan Collection and Archives of the Department of History of Architecture and of Monuments, no. 105212-105242. 


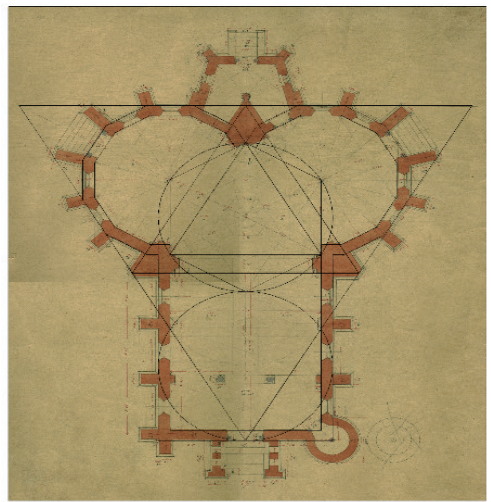

Fig. 5 Steps of the construction of the Calvinist church in Szeged (Plan Collection and Archives of the Department of History of Architecture and of Monuments, no. 101809)

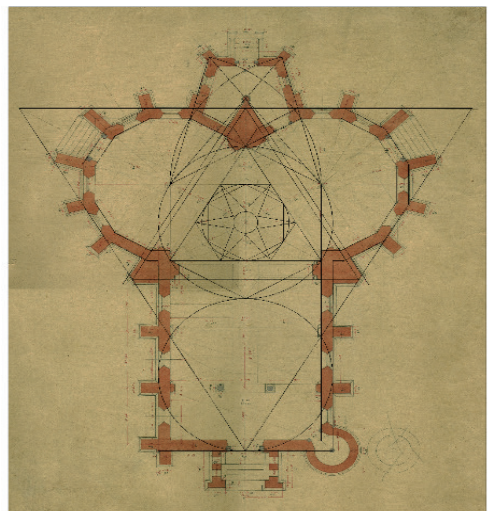

Fig. 6 Steps of the construction of the Calvinist church in Szeged (Plan Collection and Archives of the Department of History of Architecture and of Monuments, no. 101809)

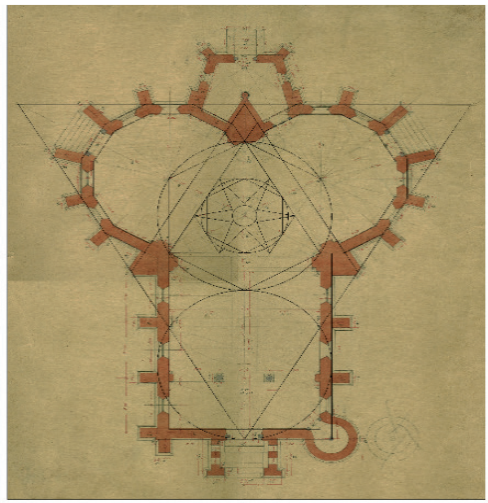

Fig. 7 Steps in the construction of the Calvinist church in Szeged (Plan Collection and Archives of the Department of History of Architecture and of Monuments, no. 101809)

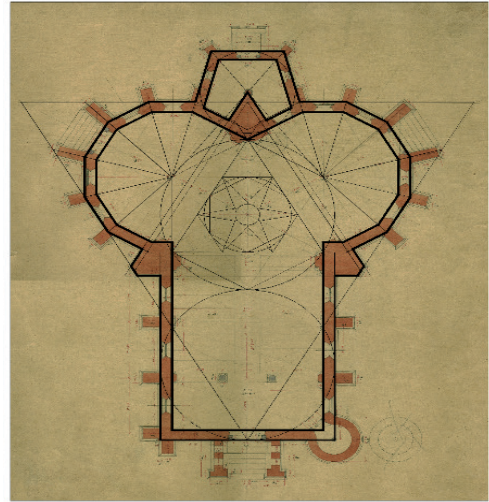

Fig. 8 Steps in the construction of the Calvinist church in Szeged (Plan Collection and Archives of the Department of History of Architecture and of Monuments, no. 101809)

\section{Inspirations}

No doubt that Schulek's geometric system is a coherently elaborated design process, however, the inspiration of which is far from obvious. The shape of the floor plan raises the question of the model role of several Norwegian Protestant churches, such as the wooden church of Holmestrand (1674) and Mo church of Surnadal (1728). (Fig. 9) These buildings were published by the German architects' society Vereinigung Berliner Architekten in 1893, so it is possible that architects like Schulek could have been aware of them a few years earlier, even though he does not refer to them in his essay. The plans of these churches are similar to a letter $Y$, which could be the prefiguration of the Calvinist Reformed Church in Szeged. One of Schulek's former plan variants with the Y-shape could support this hypothesis. ${ }^{8}$ (Fig. 10) However, the form of the three floor plans is certainly the same, the use of the interior represents different principals. In the case of the Norwegian churches, the geometric centre of the three axes of the buildings is not of importance as the communion table and the pulpit are placed in one of the wings, and the benches are placed in the other two. In Schulek's church, the importance of the centre is obvious as the communion table placed there represents both the spiritual and geometrical centre of the space. Whether Schulek was aware of the Norwegian examples, the model role of these buildings is questionable. The inspirational aspect of the ideal Protestant church plan of Leonhard Christoph Sturm however is more reasonable as it was surely known by Schulek. The ideal form of the triangle must have been an influence, though Schulek's composition is based on different principals. (Fig. 11) 


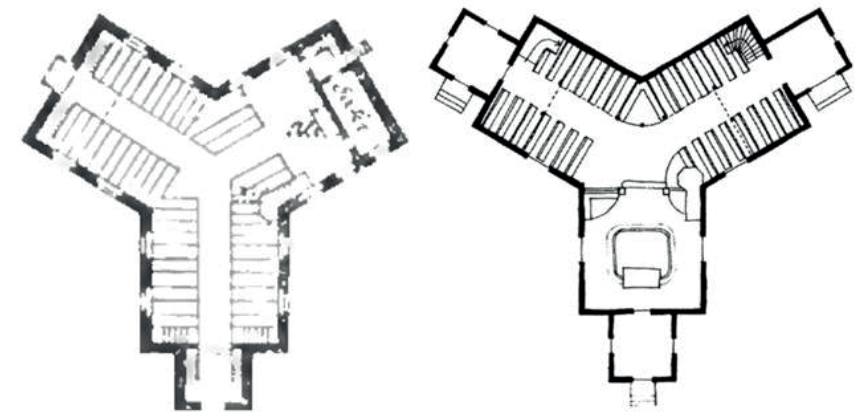

Fig. 9 Floor plan of the wooden church of Holmestrand (1674) and Mo church of Surnadal (1728) (Vereinigung Berliner Architekten, 1893)

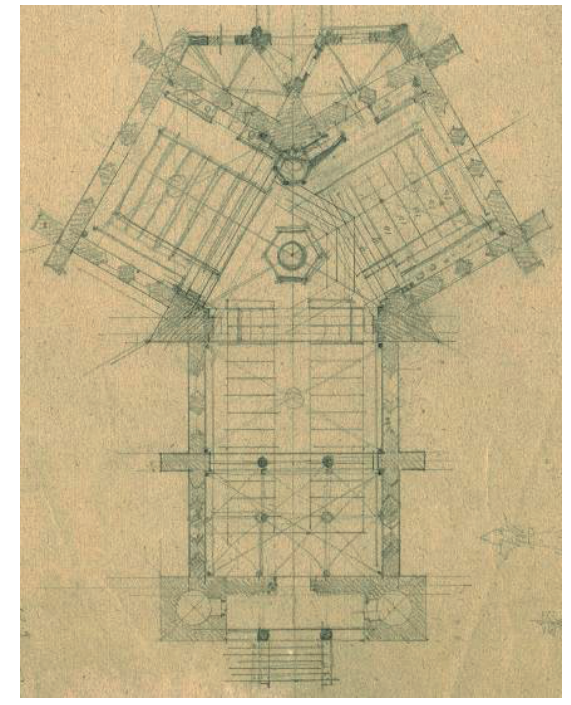

Fig. 10 A plan variant of the Calvinist Reformed Church in Szeged (Plan Collection and Archives of the Department of History of Architecture and of Monuments, no. 101796)

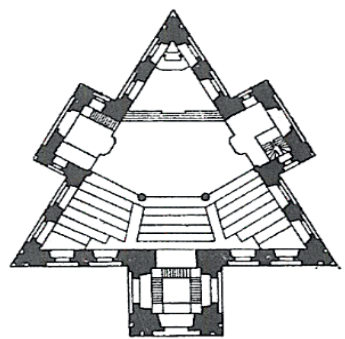

Fig. 11 The ideal plan of a Protestant church by Leonhard Christoph Sturm (Kirchenbau, 1893)

The use of the triangulation claims Schulek's approach to Medieval design methods, which he had a concept of having surveyed hundreds of historical monuments during his studies and educational practice. Medieval geometric design methods can be classified into two groups based on the main plane figure, majorly a square or a triangle. The origin of the terms 'ad triangulum' and 'ad quadratum' is likely to date back to the dispute of the construction of the Milan Cathedral from 1388 to 1401 (Ackerman, 1949; Sódor, 1978:p.18). This written source of the conversation of architects and other experts claims that the builders asked for external help in the decision as to whether they should raise the height of the main nave 'to the square or the triangle'. ' (Fig. 12) Although the earliest appearance of the terms is considered to date back to the end of the $14^{\text {th }}$ century; the square and the triangle were already used much earlier as the sketchbook of Villard de Honnecourt shows from about 1230. He used these geometric figures as the basis for the majority of his sketches, drawing either architectural plans, cross sections, details or ornamental figures. Both the triangle and the square were used throughout the Medieval period, according to late Gothic written sources such as the book on drawing pinnacles and gables by Matthes Roriczer ${ }^{10}$ and Hans Schmuttermayer or Lorenz Lechler's architectural handbook ${ }^{11}$. However, by the end of the $15^{\text {th }}$ century, the square was generally the architect's preferred choice.
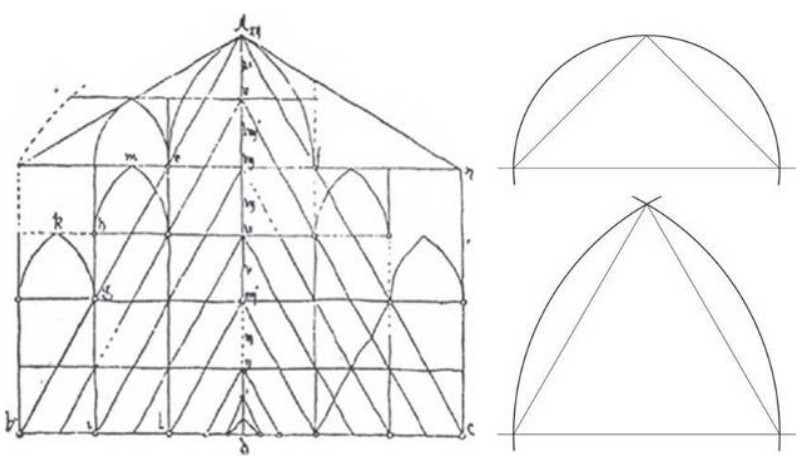

Fig. 12 Sketch of Gabriele Stornalocco for the solution 'ad triangulum' of the cross section of Milan Cathedral and a hypothetical interpretation of the question of 'ad quadratum' and 'ad triangulum' in connection with the shapes of vaulting systems. (Fehér and Halmos, 2015. 267.)

Schulek's design method for the Szeged Church was assuredly not a copy of an existing Medieval system, but its principals undoubtedly refer to the Middle Ages. Comparing his approach to the theoretical papers written on the subject by other personalities of his time, it is also important. The question of Medieval design methods was particularly the focus of interest of 19th century intellectuals trying to find the 'secret' of the harmony in Gothic buildings. Although the question was already current in the international literature of the $18^{\text {th }}$ century (Zádor, 1966), in Hungary, the first theory of the subject was worked out by Imre Henszlmann in the 1860s. ${ }^{12}$ Though his theory on Medieval proportioning methods was certainly false,

9 'The question is whether the church, not counting the dimensions of the crossing tower to be built, should rise up »ad quadratum « or »ad triangulum «.' (authors' translation) Kérdés, vajon a templom, nem számítva bele a még felépitendö négyezeti torony méreteit, ad quadratum vagy ad triangulum szerint emelkedjen-e a magasba. (translated to Hungarian by Alajos Sódor) (Sódor, 1978. 18.)

10 Matthes Roriczer: Büchlein von der Fialen Gerechtigkeit, 1486; Wimpergbüchlein, 1486-1490

11 Unterweysungen und Lehrungen für seinen Sohn Moritz, 1516

12 (Henszlmann, 1860) Imre Henszlmann worked out an arithmetical proportioning system based on the 'cube-triangle' and its transformations. For more about Henszlmann's theory see Fehér and Halmos (2015). 
it represents a particular example of the numerous hypothesis of that time. Partially to dispute the former hypothesis, István Möller also researched the topic in his particular way. While Henszlmann tried to define a general theory for the design methods of the Middle Ages, Möller examined profiles of carved stones to precise architectural relations (Fehér \& Halmos, 2016). Compared to these theories, the case of Schulek's church shows a different aspect by going beyond a theoretical level. He used his knowledge in his architectural practice and had the intention to design in a Medieval manner. The question as to whether other architects of the time practised similarly would demand further research.

\section{Conclusion}

It is hard to confirm the exact archetypes used by Schulek while designing his Szeged church; the analysis of his work certainly shows his approach and enthusiasm towards Medieval architecture and his knowledge of it. His geometrical system set an example for later churches such as the Calvinist Reformed Church of Buda by Samu Pecz, where the geometric concept of the plan and the position of the communion table and the pulpit follows the same idea (Róka, 1999:pp.27-30; Baku, 2015:p.30). (Fig. 13) The innovative solution for the intersection of the historical longitudinal Calvinist church type and the central plan which serves the functional demands, had an influence in the early $20^{\text {th }}$ century as well, for instance on the Calvinist church plans of József Borsos (Rácz, 1990:p.25,p.53.). The importance of Schulek's church is the early realisation of this conflict between function and form, which inspired Pecz to analyse and summarise the architectural demands of Protestant churches in 1888 (Pecz, 1888). Schulek's and Pecz's effect on several later centrally shaped Calvinist churches in the oeuvre of Ottó Sztehlo, Imre Francsek, Lajos Murányi, Gyula Szvoboda, Aladár Árkay is indisputable (Baku, 2014:p.31). The importance of this case study is that a particular example of Historicism can be claimed. Schulek revivified not only the visual and constructional levels of gothic architecture, but he gave rebirth to a design method, which can be regarded as a sort of Historicism of the theory of design. This shows an entirely important aspect of Schulek's architecture which is totally in accordance with his principles written in the notes to his lectures at the Royal Joseph University. He considered rationality as the essence of architecture, which means the appreciative use of historical forms - and by no means their visual copy - on the basis of the initial circumstances: function, material and topographic situation (Salamon, 2014:p.347). The Calvinist church of Szeged is a perfect verification of this ars poetica.

In another more general approach, the new space concept of the Szeged Reformed Church is not only interesting for its attempt to adapt the design technique of Medieval architecture. The church is a kind of response to the critical approaches to the Eisenacher Regulativ raised by German architects specialised in Protestant church architecture. Since the early years of the 1880 s, a polemic on a more rational form of Protestant churches emerged and increasingly determined the common talk between architects and the public (Seng, 1995:pp.326332.). As an answer to this issue, the growing importance of the chancel - extended, for example, with transepts of polygonal layout - appeared to be the solution. Looking at Schulek's unique and well elaborated ground plan conception designed in 1882, the Szeged Reformed Church is a genuine response to this European-wide problematic.

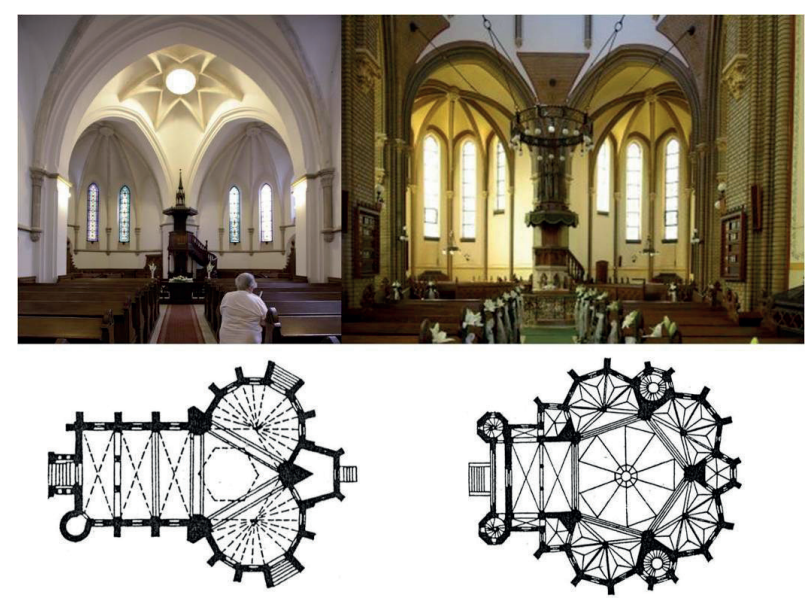

Fig. 13 Interior and floor plan of Schulek's Calvinist Reformed Church in Szeged and Pecz's Calvinist Reformed Church in Buda (photo by Zorán Vukoszávlyev)

\section{Acknowledgement}

Authors would like to express their special thanks for Zorán Vukoszávlyev for his photos. This work was supported by the National Research, Development and Innovation Fund (NKFIA) under Grant Number 112906.

\section{References}

Ackerman, J. S. (1949). "Ars sine scientia nihil est". Gothic Theory of Architecture at the Cathedral of Milan. The Art Bulletin. 31(2), pp. 84-111. https://doi.org/10.2307/3047224

Baku, E. (2015). A 20. század első felének centrális templomai. (Central churches of the first half of the $20^{\text {th }}$ century). Credo: Evangélikus Mühely. [Online]. Available from: <http://real.mtak.hu/28908/1/Credo_201502_27_37_Baku_Eszter_2_u.pdf $>$ [Accessed: 20th May 2016] (in Hungarian)

Bork, R. (2011). The Geometry of Creation: Architectural Drawing and the Dynamics of Gothic Design. Ashgate, Farnham.

Fehér, K., Halmos, B. (2015). A középkori építészet szerkesztési módszerei a hazai szakirodalom tükrében. (Architectural design methods of the Middle Ages by the Hungarian historiography.), Épités-Épitészettudomány. 43(3-4), pp. 237-284. https://doi.org/10.1556/096.2015.43.3-4.7 (in Hungarian)

Fehér, K., Halmos, B. (2016). Középkori szerkesztőmódszerek kutatása Möller István életmüvében. (Research of Medieval constructing methods on the oeuvre of István Möller.), Müemlékvédelem. 60(1-2), pp. 86-100. (in Hungarian) 
Henszlmann, I. (1860). Méthodes des proportions dans l'architecture égyptienne, dorique et du Moyen Âge. Paris. (in French)

Pecz, S. (1888). A protestáns templomok építéséről, kapcsolatban a debreceni kálvinista új templom részletes ismertetésével. (About the building of Protestant churches in connection with the detailed description of the new Calvinist reformed church of Debrecen.) A Magyar Mérnök és Épitész Egylet Közleményei. 22(5), pp. 193-205. (in Hungarian)

Pecz, S. (1888). A protestáns templomok építéséről, kapcsolatban a debreceni kálvinista új templom részletes ismertetésével. (About the building of Protestant churches in connection with the detailed description of the new Calvinist reformed church of Debrecen.), A Magyar Mérnök és Épitész Egylet Közleményei. 22(6). pp. 241-251. (in Hungarian)

Rácz, Z. (1990). Borsos József és Debrecen korai modern épitészete. (József Borsos and the Befginning of Modern Architecture in Debrecen.), Debrecen. (in Hungarian)

Róka, E. (1999). A budai református templom. (The Calvinist Reformed church of Buda.) Budapest. (in Hungarian)

Salamon, G. (2014). “Aztán vigyázzon, el ne csússzék...” - Elmélet, gyakorlat és fontolva haladás a múegyetemi Schulek-tanszéken. ('Be careful there, don't slip...' - Theory, practice and tentative progress in the Schulek Department of the Technical University.) Ars Hungarica. 15(3), pp. 338350. (in Hungarian)
Schulek, F. (1885). A református templom Schulek Frigyestől. (The Calvinist Reformed church from Frigyes Schulek.) Az Épitési Ipar, Offprint Issues. (in Hungarian)

Seng, E.-M. (1995). Der Evangelische Kirchenbau im 19. Jahrhundert. Die Eisenacher Bewegung und der Architekt Christian Friedrich von Leins. Ernst Wasmuth Verlag Tübingen. (in German)

Sódor, A. (1978). Az épitészeti tervezés alaptendenciái a középkorban. (Basic tendencies of architectural design in the Middle Ages.) Egyetemi jegyzet. Müszaki Egyetem Építésztetörténeti és Elméleti Intézet Mủemléki Osztály, Budapest. (in Hungarian)

Vereinigung Berliner Architekten. (ed.) (1893). Der Kirchenbau des Protestantismus von der Reformation bis zur Gegenwart. Berlin Kommissions - Verlag von E. Toeche, Berlin. (in German)

Zádor, A. (1966). Henszlmann Imre építészetelmélete és a gótizálás kialakulása. (Architectural theory of Imre Henszlmann and the evolution of gothic revival.), Épités- és Közlekedéstudományi Közlemények. 10(2), pp. 207228. (in Hungarian) 